seaworthiness of the vessel".

The board points out, for example, that although the chief scientist principal scientist was "a highly regarded investigator with considerable knowledge and experience in ocean research", there was no evidence that he or the other scientists had expertise in vessel seaworthiness, stability, or navigation.

The board also raises questions with regard to the adequacy of procedures adopted by the university for observing guideline safety standards for research vessels laid down in may 1976 by the University National Oceanographic Laboratory System (UNOLS), based at Woods Hole in Massachusetts, an Association of Oceanographic Institutions.

\section{Drought could turn Dead Sea into a desert}

Crossing the Dead Sea on foot is now theoretically possible - if it weren't for the presence of border patrols - according to Shlomo Drori, a leading Israeli expert on the use of Dead Sea resources. Following the worst drought in the history of the State of Israel, the sea has split in two at its narrowest point.

The Dead Sea's sole feeder is the lower Jordan, which is becoming increasingly depleted by water developments, both Israeli and Jordanian. Last November, even before the onset of the drought, Yigal Allon, the former Israeli foreign minister spoke in the Knesset of the "urgent" problem of the Dead Sea. Current Jordanian water projects involve the damming of all eastern tributaries of the Jordan; when these are completed, said $\mathrm{Mr}$ Allon, the lower Jordan would totally disappear save as a drainage channel, the Dead Sea level would fall signifacantly, and the southern part of it would become a salt desert. This, as the Energy Minister Yitzak Moda'i admitted in his reply to $\mathrm{Mr}$ Allon, could cause "tremendous" and possibly irreversible ecological damage.

It is, however, Israel's water schemes which are the main consumers of sources which would, without human intervention, end up in the Dead Sea. For the lower Jordan flows from the sea of Galilee, which, via the National Aquifer, serves as the water source of the whole country. According to Professor Yoram Avnimelech, a soil chemist seconded from the Technion to the Sea of Galilee Conservancy Board, considerable problems are posed to conservationists by the unique status of the Sea of Galilee, including its religious and historical associations. The normal way of treating a
It points out that although these include "an excellent array of standards and procedures which would be applicable to most research vessel operations", and despite the fact the University of Hawaii is member of UNOLS, the guideline standards had not been applied to the Holoholo, which was not owned by the university but had been commissioned through a subcontract with the university's research corporation.

As a result, says the board, the operation of the Holoholo apparently relied on the charter contractor for vessel seaworthiness, on the contract with the boat's master - of whom there is no evidence or expertise in vessel stability for safe operation, and on the judgement of the chief scientist as to the suitability of the vessel to serve as a platform for the research projects to be conducted.

"There is no evidence that any of the guidelines standards were considered or applied by three individuals involved or by any other officials of the university or research corporation" the board says.

Officials at the university, which may be sued for substantial damages by the relatives of those on board the vessel when it disappeared, have declined so far to make any public statement about the incident, apart from saying that the specific recommendations of the safety board to prevent similar occurences in the future" are now under study by university officials.
David Dickson

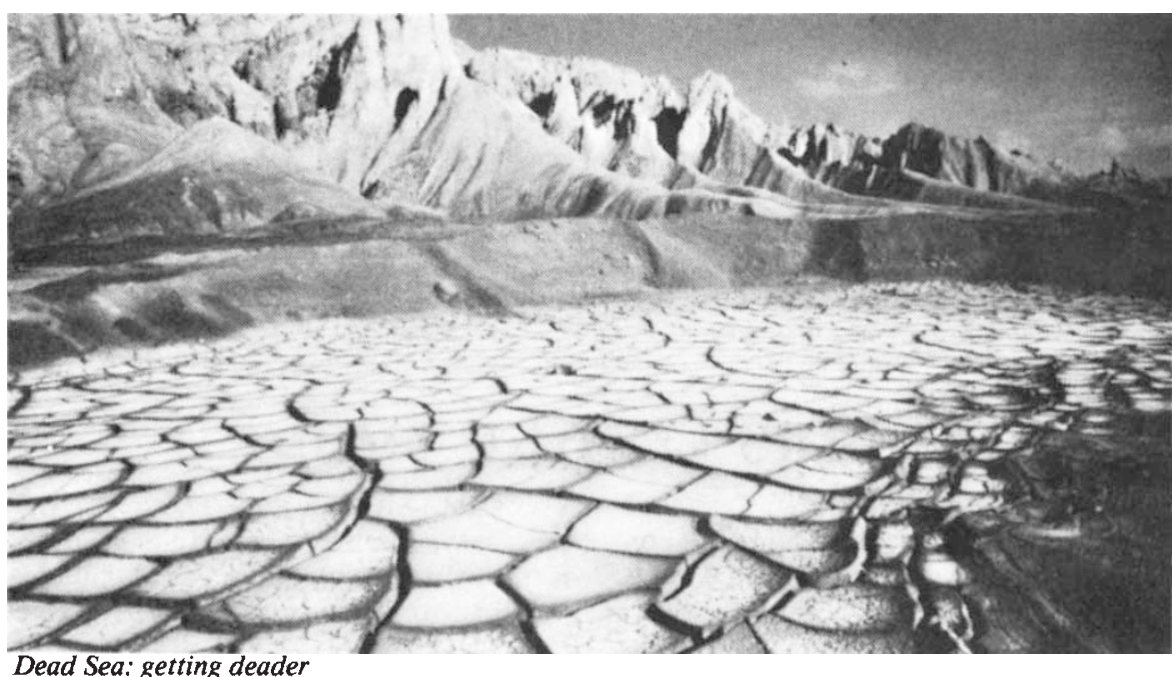

lake scheduled as a drinking water source, he told Nature, is to fence it off, minimise development of the watershed, and try to keep the population out. This, however, is not possible in Israel, which has a limited supply of water - indeed, in the summer, every drop of water from the springs of the Upper Galilee is used three times by irrigation and fish-farming schemes before it even reaches the Sea of Galilee.

On occasion, the needs of the Conservancy seem to run counter to Israeli national sentiment. In 1968, workers at the Limnological Laboratory at Tevhag began to observe excessive levels of nitrates in the water, due not only to the use of fertilisers in the Upper Galilee but also to the uncovering of the organic soils of the Huleh valley. Since the reclamation of the Huleh marshes has attained a saga-like status in Israeli history, the obvious alternative of reflooding the Huleh was simply not acceptable, but it took several years of intensive research before a suitable strategy was devised to obviate the danger of eutrophication posed by the excess nitrates. (This is based, incidentally, on short-term sprinkling of the Huleh soil at high summer temperatures to encourage the action of denitrifying bacteria).

Professor Avnimelech, who is very much the scientific trouble-shooter for the Sea of Galilee Conservancy, also indicated another area where Jewish sentiments and the needs of conservation may yet clash. "Planting a tree in Israel" is a tradition with considerable emotional overtones to Israeli and Diaspora Jews alike - yet recent indications, Professor Avnimelech said, suggest that over-zealous treeplanting in the Galilee watershed may be causing environmental deterioration.

Yet, however well the Water Conservancy Board husbands the Galilee resources in times of drought, the Sea of Galilee itself may be at risk. This summer, the water level fell dangerously low, and when the rain finally fell just before Jewish New Year, one official revealed that no water had been taken from the Sea of Galilee for almost four months - the country had been subsisting solely from supplies stored in auxiliary reservoirs along the aquifer.

As far as the depleted - and now divided - Dead Sea is concerned, there does exist one fairly obvious means of replacing the waters lost to human needs. This is the construction of a canal to bring in water from the Mediterranean. Israel, of course, does not have the funds to contemplate such a scheme merely as an ecological rescue operation. However, the Dead Sea lies some $400 \mathrm{~m}$ below the level of the Mediterranean, so that, the canal could descend via series of hydroelectrical cascades which could according to current calculations, produce up to $10 \%$ of Israel's 
present generating capacity. Although, according to Energy Minister Moda'i, electricity can still be generated more cheaply using fossil-fuelled power stations, granted the need for such a canal, powerproduction might make it economic.

One early exponent of such a canal was American pioneer of land conservation, William Clay Lowdermilk. In 1939, Lowdermilk formulated an "eleventh commandment" for the future state of Israel. This reads, in part: "Thou shalt safeguard thy fields from soil erosion, thy living waters from drying up ....". This summer's drought has made it imperative that this "commandment" should be extended to include not only the "living" waters of the Jordan and Sea of Galilee but also those of the Dead Sea.

Vera Rich

\section{UK plans nuclear expansion}

BRITAIN'S Conservative government is expected to announce details of a $£ 10 \mathrm{bn}$ nuclear expansion programme within the next few weeks. The plan will involve building up to 20 nuclear reactors to supply half Britain's electricity needs by the year 2000. The Conservative cabinet is unanimous in its support for nuclear power, the only disagreements being over reactor type.

At present it is believed the American pressurised water reactor of the type involved in the Harrisburg accident is the leading candidate because it can be brought on line in five years, half the time needed by the advanced gas cooled reactor. Two public inquiries will be held before the plan can be enacted. One is a planning inquiry about the siting of the PWR, the other a full public inquiry about the necessity for a fast breeder reactor for Britain's nuclear future. Although strong opposition plan to counter it. "They will wait and see how effective the opposition is before taking counter measures"' a Department of Energy spokesperson told Nature.

USSR questions nuclear safety: For the first time, the Communist Party has published an article on negative environmental effects of nuclear power. The article, in Kommunist, the party's theoretical journal, was co-authored by Nikolai Dolezhal, a prominent nuclear scientist, and Yurii Kroyakim, a relatively unknown economist. It questions the amount of valuable agricultural land that would be used, the effect on water supplies and the difficulties of storing nuclear wastes.

The article stresses that the sheer scale of the programme involving an expansion from the present level of 10 million $\mathrm{kW}$ to over 110 million $\mathrm{kW}$ by 1990 plus the construction of nuclear power stations in western Soviet cities as sources if district power heating would encroach considerably on agricultural land. Previous Soviet comment has characterised the anti-nuclear movement as being inspired by oil companies anxious to preserve their market position.

French demo blocks fuel: In a militant demonstration against nuclear fuel reprocessing, French trade unionists and environmentalists held up the unloading of Nearly 2,000 demonstrators met the ship chartered by British Nuclear Fuels Ltd when it docked at Cherbourg on 9 October with its cargo for reprocessing at nearby $\mathrm{La}$ Hague.

Demonstrators blocked a railway siding, severed an electric cable and put a crane out of action in a successful attempt to block the unloading. The Socialist Party and the socialist trade union federation the CFDT are demanding a national debate to prevent France from becoming "the nuclear dustbin of the world".

Waste disposal plan could take a decade: An independent waste disposal plan produced by the state of California has caught the nuclear industry by suprise. The plan calls for simulated waste to be placed in experimental vaults 1000 metre under ground in variety of geological formations. Measurements would be taken on migration rates as a function of rock type, temperature, depth, and pressure and the findings compared to theoretical predictions.

The entire process would take ten years and is recognised to be the only valid way to assess present underground storage plans. The federal government accused the state government of ignoring national energy policy and of failing to keep Washigton informed. The move is widely regarded as a show of strength by the anti-nuclear movement and is expected to give a boost to California governor Jerry Brown's campaign for the presidency.

Protestors march in Bonn: In the largest demonstration since the early 1930s, protestors demanded an immediate end to the development of nuclear power is West Germany. Individual columns stretched more than $2 \frac{1}{2}$ miles as 100,000 activists including representatives from the US Austrian, Danish, Dutch, French and Swedish anti-nuclear movements converged on Hofgarten park in central Bonn last Sunday. Demonstrators gave a standing ovation to a speech from Kathy McCaughin of the Harrisburg Citizens Action Group who called for a stop to "the nuclear madness now". Trade union speakers were applauded when they said that more jobs would be created by alternative technology instead of nuclear power.

Joe Schwartz
15 tons of spent nuclear fuel from Japan.

\section{Syrians blast UNCSTD over power politics}

SYRIA'S delegation to UNCSTD returned home unsatisfied and a little angry. "We know that the problems of development cannot be solved with one conference, but at least we could have made a start", says Dr A W Chahid, Director of the Centre for Scientific Studies and Research in Damascus and a leading member of the Syrian delegation.

The future for the developing countries after UNCSTD, says Dr Chahid, is " just as hazy as it was before. We came back from Vienna even more convinced of the inherent biases and injustices of the existing scientific and technological order in the world".

Most of the developing countries were not prepared for the tight, hard-nosed negotiations and power play that was conducted by the developed countries at UNCSTD. Dr Chahid is particularly critical of the petty politics and the infighting of the European Community countries. "The attitude of the Nine to the proposed Development Fund was quite pathetic", he says. (A fund of $\$ 2$ billion to 1985 proposed by the Group of 77 was cut to $\$ 250$ million to 1981 .) The Nine were also responsible for frustrating the good intentions of "the Nordic Group which was quite forthcoming and ready to make a reasonable contribution to the fund".

Dr Chahid thinks it was unfortunate that the Group of 77 was dominated by countries that are at the top of the development continuum. India, Brazil, Yugoslavia and other members of the 'Group of 27' of the Group of 77 who took part in the negotiations have a reasonably developed scientific and technological infra-structure. "It is these countries which stand to gain most out of the few achievements of UNCSTD".

But what about the really poor countries that suffer from the "small country problems", that do not have even the tiniest form of science and technology infrastructure? "What do they get out of UNCSTD?" asks Dr Chahid. "We must ensure that they get the lion's share of the Development Fund, little though it is".

The power and coordinating ability of the Group of 77 will be tested to the full in the setting up of the UN intergovernmental committee that will administer the Development Fund. Dr Chahid argues that if all members of the Group of 77 took an active interest in the intergovernmental committee and if there was "a very strong Group of 77 representation on the Committee", it may be possible to steer development in the Third World's favour.

However, Dr Chahid points out that many developing countries, including Syria, do not have a representative in New York. 